\title{
“GENETIC EVALUATION OF REPRODUCTIVE TRAITS IN RELATION TO PRODUCTION TRAITS IN ORGANIZED HERD HOLSTEIN FRISIAN IN INDIA"
}

\section{VIPIN KUMAR SINGH ${ }^{1}$, RAMPAL SINGH ${ }^{2}$, NEERAJ ${ }^{3}$, RAMESH PANDEY ${ }^{4} \&$ ANUPAMA MUKHERJEE ${ }^{5}$}

${ }^{1}$ Ph.D. Scholar, SHUATS, Allahabad India

${ }^{2}$ Associate Professor, AG \& B Department, SHUATS, Allahabad India

${ }^{3}$ Dean Faculty, SHUATS, Allahabad India

${ }^{4}$ Professor, SHUATS, Allahabad India

${ }^{5}$ Principal Scientist, DCB,NDRI,Karnal, Haryana,India

\begin{abstract}
The motive of this study to more information of genetic information (like heritability, genetic correlation) of HF imported sires germ plasma and Indian HF sires germ plasma used in India. Data was collected from an organized HF dairy farm Bhagylaxmi Dairy farm Manchar Pune recorded year from 2007 to 2014. Estimated heritability (h2) for FLTMY, FL300/305DMY, Age of first calving, First lactation length, First dry period, First calving interval were $0.24 \pm 0.08$, $0.32 \pm 0.09,0.2 \pm 0.79,0.13 \pm 0.06,0.10 \pm 0.06,0.19 \pm 0.076$ respectively. Genetic correlation of FLTMY with FL300/305DMY, FCI, FDP, FLL were found to be strongly positive $0.91,0.70,0.5$, and 0.78 , respectively. Whereas, genetic correlation of FLTMY with AFC was observed to be weakly positive 0.14. Genetic correlation of FL300/305DMY with FLL, AFCfound to be strongly positive 0.60, 0.76, respectively and genetic correlation of FL300/305DMY with FDP, FCI was observed positively weak $0.20,0.35$, respectively. Genetic correlation between $F C I$ and $F D P, L L$, was found to be strongly positive $0.68,0.88$ respectively. Genetic correlation between FCI and AFC was found to be medium positive 0.40. Genetic correlation between FLL and FDP was observed be weakly positive 0.13. Whenever, genetic correlation between FLL and AFC was found to be weakly negative -0.13. The heritability for production and reproduction were found to be low in this study. This means production and reproduction traits affected by the environment. Genetic correlation between two traits was observed to be highly positive or highly negative. It indicates that traits are influence by same gene.

Keywords-: Heritability, Holstein-Frisian, Genetic Correlation, Phenotypic Correlation.
\end{abstract}

Received: Sep 06, 2020; Accepted: Sep 26, 2020; Published: Nov 20, 2020; Paper Id.: IJASRAUG202035

\section{INTRODUCTION}

To Genetically superior dairy herd first need to knowledge of genetic and phenotypic parameter is required for breeding policy to improvement herd according to objective. Heritability is very important genetic parameter which is relationship between genotypic and phenotypic value of individuals. In multivariate quantitative genetic, genetic correlation is the proportion of variance that two traits share due to genetic influence, phenotypic correlation is the proportion of variance that two traits share due to genetic and environmental influence. These genetic parameters are very important tool for deciding, designing and making breeding policy accordingly.

In India various workers estimate of heritability and correlation between economical traits in different breed of dairy cattle. Pol et al. (2013), Shelke(2012) were studies on Phule Triveni. Nehra(2011) and Singh (2013) reported on Karan Fries crossbred cattle, whereas Mukherjee(2005) study focused on Frieswal crossbred. 


\section{Materials and Methods}

Data were collected from Bhagylaxmi dairy farm Manchar Pune, Maharashtra, India. Data was maintained by animal software (Dairy plan).Present study was conducted on 973 dams and 42 sires.

Paternal half sib correlation method (Becker, 1975) will be used to estimate $h^{2}$ of first lactation traits using the following model:

$$
Y_{i j}=\mu+S_{i}+e_{i j}
$$

where,

$$
\begin{aligned}
& Y_{i j}=\text { Observation on } j^{\text {th }} \text { progeny of } i^{\text {th }} \text { sire } \\
& \mu=\text { Overall mean } \\
& S_{i}=\text { Effect of } i^{\text {th }} \text { sire } \\
& \mathrm{e}_{\mathrm{ij}}=\text { Random error NID }\left(0, \sigma_{\mathrm{e}}^{2}\right)
\end{aligned}
$$

The $S_{i}$ and $e_{i j}$ are assumed to be independent of each other.

\section{Analysis of Variance}

\begin{tabular}{|l|c|c|c|}
\hline Sources of Variation & df & Mean Squares & $\begin{array}{c}\text { Expected } \\
\text { Mean Squares }\end{array}$ \\
\hline Between sires & S-1 & MSSs & $\sigma^{2}{ }_{\mathrm{e}}+\mathrm{K} \sigma^{2}{ }_{\mathrm{s}}$ \\
\hline Within sires & $\mathbf{N}-\mathrm{S}$ & $\mathbf{M S S}_{\mathrm{E}}$ & $\sigma_{\mathrm{e}}^{2}$ \\
\hline
\end{tabular}

Where,

$\sigma^{2}$ : mean sum of square due to error

$\sigma_{\mathrm{s}}^{2} \quad$ : sire component of variance

$\mathrm{K}$ : average number of progenies per sire

$$
t=\frac{\sigma^{2} \mathrm{~s}}{\sigma^{2} \mathrm{e}+\sigma^{2} \mathrm{~s}}
$$

$h^{2}=4 t$

Becker (1975) gave genetic and phenotypic correlation among traits was estimated from the analysis of variance and covariance among sire groups.

\section{Genetic correlation $\left(\mathbf{r}_{\mathrm{g}}\right)$}

The genetic correlation between two traits was estimated as:

where,

$$
r_{g}(x, y)=\frac{\operatorname{Covs}(x, y)}{\sqrt{\sigma^{2} s(x) \cdot \sigma^{2} s(y)}}
$$




$$
\begin{aligned}
& \operatorname{Cov}_{\mathrm{s}}: \text { sire components of covariance between traits } \mathrm{x} \text { and } \mathrm{y} \\
& \sigma_{\mathrm{s}(\mathrm{x})}^{2}: \text { sire components of variance of trait } \mathrm{x} \\
& \sigma_{\mathrm{s}(\mathrm{y})}^{2}: \text { sire component of variance of trait } \mathrm{y}
\end{aligned}
$$

\section{RESULT AND DISCUSSION}

Heritability estimation of first lactation total milk yield (FLTMY) found to be $0.24 \pm 0.08$. The value indicated that the heritability is medium for milk production and genetics played significant role in the performance of animal as far as milk production is concerned. The estimation of heritability was observed in this study were observed similar reports of first lactation total milk yield reported by various workers in different crossbred and Triple crossbred was $0.041 \pm .020$ in FJG,

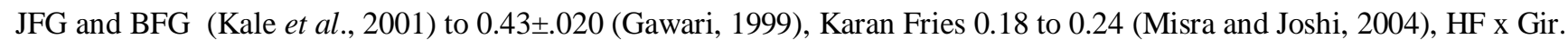
Heritability estimation of FL300/305DMY was reported $0.32 \pm 0.09$. The estimate indicated that the heritability is medium for milk production and genetics played significant role in the performance of animal as far as milk production is concerned. Shelke (2012) the heritability estimated $0.47 \pm 0.11$ in Phule Triveni three cross whereas Mukherjee(2005) was observed $0.20 \pm 0.04$.

Estimation of heritability for AFC found to be0.193 \pm 0.079 . The estimate indicated that the heritability lower for age of first calving. Therefore much emphasis needs to be placed on the selection of breeding animals. Due care needs to be given for genetic evaluation of high genetic worth of animals in the herd. Saha (2001) heritability of AFC was reported $0.17 \pm 0.09$ in KF. Singh (2013) and Divya (2012) heritability for age of first calving(AFC) was reported $0.55 \pm 0.13,0.54$ \pm 0.16 respectively in KF. Heritability of first lactation length was found to be $0.127 \pm 0.06$. The estimated indicated that the heritability is lower. Therefore much emphasis needs to be placed on the selection of breeding animals. Due care needs to be given for genetic evaluation of high genetic worth of animals in the herd. Gawari (1999)estimation of heritability for first lactation length was observed $0.47 \pm 0.12$ in crossbred cattle and Bhoite (1996) was observed $0.25 \pm 0.16$ in JG crossbred. Heritability of first calving interval was found to be $0.188 \pm .076$. Estimation indicated that the heritability is low. Therefore much emphasis needs to be placed on the selection of breeding animals. Due care needs to be given for genetic evaluation of high genetic worth of animals in the herd. Mukherjee (2005) heritability of FCI reported $0.06 \pm 0.03$ in Frieswal. Saha (2001), Panja(1997), Singh(1995) were reported heritability $0.35 \pm 0.10,0.02 \pm 0.14,0.02 \pm 0.8$ respectively in KF. Heritability of first calving interval was found to be positive low $0.093 \pm 0.061$ days. The Heritability of first dry period is low hence less possibility for improvement in this trait thought selective breeding. Deshmukhet al.(2003) was observed the heritability for dry period in Holstein Frisian x Gir crossed was 0.20, Komatwaret.al (2009) was observed the heritability for dry period in HF x Sahiwal crossbred as $0.12 \pm 0.040$.

Table 1: Estimation of Heritability, Genetic and Phenotypic Correlation for First Lactation Traits of HF Cattle

\begin{tabular}{|l|l|l|l|l|l|l|}
\hline & FCI & FDP & FLL & FL300/305DMY & FLTMY & AFC \\
\hline FCI & $\mathbf{0 . 1 8 8} \pm .076$ & $0.686^{* *}$ & $0.883^{*}$ & $0.354^{*}$ & $0.708^{*}$ & 0.4 \\
\hline FDP & $0.537^{* *}$ & $\mathbf{0 . 0 9 3} \pm \mathbf{0 . 0 6 1}$ & $0.127^{*}$ & 0.199 & $0.498^{* *}$ & NA \\
\hline FLL & $0.641^{*}$ & -0.62 & $\mathbf{0 . 1 2 7} \pm \mathbf{0 . 0 6}$ & $0.589^{*}$ & $0.781^{* *}$ & -0.133 \\
\hline FL300/305DMY & 0.122 & -0.239 & 0.47 & $\mathbf{0 . 3 1 8} \pm \mathbf{0 . 0 9}$ & $0.917^{* *}$ & $0.76^{* *}$ \\
\hline FLTMY & $0.386^{*}$ & -0.092 & 0.678 & 0.887 & $\mathbf{0 . 2 4 4} \pm \mathbf{0 . 0 8}$ & 0.144 \\
\hline AFC & 0.039 & 0.086 & -0.002 & 0.136 & 0.122 & $\mathbf{0 . 1 9 3} \pm \mathbf{0 . 0 7 9}$ \\
\hline
\end{tabular}

** Significant $(\mathrm{P}<0.01) \quad *$ significant $(\mathrm{P}<0.05)$ 
Genetic correlation between FLTMY and FL300/305DMY was observed highly significant (0.91).it means there is positively strong correlation between FLTMY and FL300/305DMY. Genetic correlation between FLTMY and First lactation length (FLL) was observed highly significant (0.78). Genetic correlation between FLTMY and First dry Period (FDP) was observed highly significant (0.49). Genetic correlation between FLTMY and first calving Interval (FCI) was observed significant (0.70). Nikam (2010) were reported significant genetic correlation between FLTMY and FL300DMY (0.99) in Pule Triveni synthetic cow where as Gawari (1999) reported positive and significant $(\mathrm{P} \leq 0.01)$ genetic correlation. Genetic correlation among FL300/305DMY with first calving interval (FCI) was reported significant (0.35). Genetic correlation among FL300/305DMY with First dry period (FDP) was reported non-significant (0.12). Genetic correlation among FL300/305DMY with first lactation length (FLL) was reported significant (0.59). Correlation between FL300/305DMY and calving interval and first lactation length was strongly positive whereas correlation between FL300/305DMY and first dry period is low and positive. Pol et al.(2013) was observed (-0.11) genetic correlation between FLL and FL300DMY in Phule Trivenitriple cross cattle where as Nikam (2010) was observed significant (-0.786) genetic correlation between FLL and FL300DMY in Pule Triveni triple cross cattle. Genetic correlation between AFC and FCI was observed positive correlation non-significant 0.40 . Genetic correlation between AFC and first lactation length (FLL) was reported negative correlation non-significant -0.133. Genetic correlation between AFC and FL300/305DMY was reported positive correlation significant 0.076. Genetic correlation between AFC and FLTMY was reported positive correlation non-significant 0.144. Its indicate correlation AFC and FCI was strongly positive if you are selecting one trait second trait will be automatically improve in herd. In other hand genetic correlation between AFC and FLL was negative correlation it means selection of one trait automatically rejection of second which is negatively correlated. Singh et al. (2005) was reported genetic correlations between AFC with FLTMY and FL300DMY which were positive and significant in crossbred cattle. Genetic correlation between FLL and FCI was reported highly positive correlation significant 0.88 . Genetic correlation between FLL and FDP was observed low positive correlation significant 0.127. Genetic correlation between FDP and FCI was found to be highly positive correlation significant 0.686 . Its indicated that if we want reduce dry period calving interval automatically reduce by selection in a herd.

\section{CONCLUSIONS}

Heritability is one of the most important genetic parameter for animal breeding. There are $\mathrm{h}^{2}$ for production and reproduction traits were observed moderately (from 0.15 to about 0.40 ) and low $\mathrm{h}^{2}$ (less than 0.15 ). The heritability of a trait is not deciding factor in whether to include genetic improvement program as the as the economic values even low heritability traits improved by changed by selection. Accuracy of selection of low $\mathrm{h}^{2}$ traits can be improved use of pedigree information and increased progeny group size.

Genetic correlation between two traits was found to be high and positive or high negative. It indicates that traits are influence by same gene.

\section{REFERENCES}

1. Becker, W.A. (1986). Manual of procedures in quantitative genetics. Publication of Washington, State Univ.

2. Pullman, USA

3. Bhoite, U. Y. and Kale, K.M. (1996) Production performance of three breed Gir crosses. Indian Vet.

4. J.73 (4): $473-474$. 
5. Deshmukh, D.S., Sakhare, P.G., Baig, M.I. and Dhaware, S.A. (2003). Studies on reproductive traits in

6. Holstein Friesian and Gir crossbred cows. J. Bombay Veterinary College, 11(1/2): 64-66.

7. Divya P (2012). Single versus multi-trait models for genetic evaluation of fertility traits in Karan Fries

8. cattle, M.V.Sc. Thesis submitted to NDRI, Karnal.

9. Gawari, R. G. (1999). Genetic studies on persistency of milk yield in triple crossbred cattle. M.Sc. (Agri.)

10. Thesis submitted to MPKV.,Rahuri.

11. Kale, D.D., Ulmek, B.R., Deokar, D.K. and Pachpute, S.T. (2001). Studies on lactation milk yield in triple

12. crossbred cattle. J. Maharashtra Agri. Univ. 26(3): 316-319

13. Komatwar, S. J., Deshpande, A.D., Kulkarni, M. D., Kulkarni, A. P., Yadav, G. B., Shisode, M. G and

14. Khanvilkar, A. V. (2009). Study of genotypic and phenotypic correlations on production traits in

15. HolsteinFriesian x Sahiwal crossbreds J Bombay. Vet. College, 17 (1): 70-71.

16. Mukherjee, S. (2005). Genetic evaluation of Frieswal cattle Ph.D. Thesis, National Dairy Research Institute

17. Karnal, (India).

18. Misra, S. and Joshi, B.K. (2004). Genetic and non-genetic factors affecting lactation milk constituents

19. and yield traits in Karan Fries cattle. Indian J. Dairy Sci., 57 (1):69-72.

20. Nehra, M. (2011) Genetic analysis of performance trends in Karan Fries cattle. M.V.Sc. Thesis. NDRI

21. Karnal, India.

22. Nikam, R. A. (2010). Effect of age and weight at first calving on reproduction and production performance PhuleTriveni synthetic cow. M.Sc. (Agri.) Thesis submitted to MPKV, Rahuri.

23. Panja,Research Institute (Deemed University), Karnal, India.

24. P. (1997). Optimization of economic traits in Karan Fries cattle. M.Sc. Thesis,NDRIKarnal.

25. Pol, K. E., Dhage, S. A., Pachpute, S. T. and Khutal, B. B.(2013). Generation wise production

26. efficiency of PhuleTriveni synthetic cow. J. Agric. Res. Technol., 38 (1): 117- 129.

27. Saha, D.N. and Khan, F.H.(1980). Lactation length in Gir cows. Indian J. Dairy Sci., 18(1):2224.

28. Shelke M. G.(2012). Generation wise persistency of milk production in PhuleTriveni Synthetic cows M.Sc.

29. (Agri.) Thesis submitted to MPKV, Rahuri

30. Singh R. K. (2013). Genetic evaluation of Karan Fries sires using multiple trait models. Ph.D. thesis

31. submitted to NDRI, Karnal (Haryana).

32. Singh, V. K., Singh, C.V., Kumar, D. and Kumar, A. (2005). Genetic evaluation of some economic traits

33. inSahiwal and its crossbreds. Indian J. Dairy Sci., 58 (3): 206

34. Singh, M.K. (1995). Factors affecting trend in performance of Karan Swiss and Karan. Fries cattle. Ph.D.

35. Thesis, NDRI (Deemed University) Karnal, India. 
36. Koots, K.R., J.P. Gibson, C. Smith and J.W. Wilton,(1994). Analyses of published genetic parameter

37. Estimates for beef production traits. 1. Heritability. Anim. Breed. Abstr., 62: 309-338. 